臨床耳舅：第6卷・第1號・ 1995

Clin. Otol. pp $46 \sim 55$

Vol. 6, No. 1, 1995

$$
\begin{gathered}
\text { 중이 진주종 및 만성중이염에서 랑게르한스 세포에 관한 } \\
\text { 면역조직화학적 연구 }
\end{gathered}
$$

원광대학교 의과대학 이비인후과학교실 - 병리학교실*

이정헌 · 이재훈 · 소병수 · 강금위 · 조향정* · 문형배*

$=$ Abstract $=$

\title{
Immunohistochemical Study of Langerhans Cells in Cholesteatoma and Chronic Otitis Media
}

\author{
Jung Hun Lee, M.D., Jae Hoon Lee, M.D., Byung Soo Soh, M.D.,
} Keum Wee Kang, M.D., Hyang Jeong Cho*, M.D., Hyung Bae Moon*, M.D., Department of Otolaryngology . Pathology*, College of Medicine

Wonkwang University

Middle ear cholesteatoma is biologically invasive keratinizing squamous epithelial cyst that contains the desquamated debris. And it is clinically important entity because it causes destruction of adjacent bones and serious complications.

The pathogenesis and pathophysiology of cholesteatoma has been debated but there are basic theories of epithelial ingrowth and metaplasia of middle ear epithleium. Also there is concept that expanding process of desquamation causes bone destruction and that it may be due to proteolytic enzymes such as collagenase. Recent works suggest that Langerhans cells have an immunologic altering function and have a role of generating and maintaining the chronic inflammatory reacton which induces bone resorption.

The morphologic feature of cholesteatoma was similar to that of the tympanic membrane but there was a increase of Langerhans cells in cholesteatoma. Langerhans cells are the bone marrow-derived immune cells of the epidermis. They express Ia antigens and receptors for the Fc portion of IgG and complement components. Langerhans cells appear to recognize antigen and present them to T-lymphocyte and possibly macrophage.

The authors used immunohistochemical method to indentify and quantify distribution of Langerhans cells(S-100 protein), T-lymphocyte(HLA-DR, CD3) using monoclonal antibody techniques.

We compared distribution of Langerhans cells in cholesteatoma matrix, infected tympanic membrane and adjacent canal skin of chrnic otitis media of which were taken from patients during operation.

The obtained results were as follows: 
1) The Langerhans cells in cholesteatoma matrix increased significantly compared to those in chronic otitis media and post auricular skin. The Langerhans cells in chronic otitis media were more increased numbers than those in post auricular skin $(\mathrm{p}<0.05)$.

2) The Langerhans cells and $T$ lymphocytes with inflammatory reaction in subepithelial tissue of cholesteatoma were significantly higher than those chronic otitis media $(p<0.05)$.

\section{KEY WORDS : Langerhans cells $\cdot$ Cholesteatoma $\cdot$ Chronic otitis media Immunohistochemistry.}

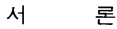

중이 진주종은 만성중이염과 달리 주위 조 직의 손상이나 이소골을 포함한 골과괴 정도가 심하여 심한 전음성 난청을 초래할뿐만 아니라 미로염, 뇌막염, 뇌농양, 측정맥동염, 안면신경 마비 등과 같은 이성 및 두개내 합병증을 초 래하기 쉽다. 또한 수술후에도 재발율이 높아 임상적인 측면에서 매우 중요한 질환이다.

중이 진주종은 발생원인에 따라 선천성은 태생기 표피아의 미입으로 발생하고, 후천성은 고막의 변연 천공이나 이완부 천공으로 진주 종을 형성하게 된다. 고실내의 각화중층편평상 피는 염중성 병변 등으로 발육이 촉진되고 탈 락된 각질이 그 속에서 축적되어 주위 골조직 을 압박괴사 하거나 Collagenase와 같은 Proteolytic enzyme에 의해 골의 Collagen이 융해 되어 골파괴를 초래하게 된다. 진주종 기질내 에 존재하는 랑게르한스 세포가 이러한 과정을 조절하는데 중요한 면역학적 역할을 할것으로 사료된다. 중이 진주종에 대한 병인, 병태생리 및 골파괴 기전에 대하여 그 동안 많은 연구가 진행되어 왔으나 아직도 규명해야할 부분이 많이 남아 있다.

랑게르한스 세포는 1868년 Paul Langerhans 에 의해 발견되어 1950 년대 전자현미경적 연 구가 이루어지기까지는 역할의 중요성에 대한 인식이 없었으나 최근 면역학의 발달로 인해 그 중요성이 재인식되면서 이에 대한 연구가 활발히 진행되고 있다. 랑게르한스 세포는 기 능상 및 면역학적으로 대식세포와 같은 계통 으로 골수로 부터 유래하며 미세구조상 세포
질내에 Birbeck 과립을 가지고 있다. 세포 표 면에는 $\mathrm{Ia}$ 항원 (혹은 HLA-DR항원)이 존재하며 $\mathrm{C} 3 \mathrm{~b}$ 및 $\mathrm{IgG}$ 의 $\mathrm{Fc}$ portion에 대한 막수용체, OKT-6 단클론항체에 의해 인식되는 세포막 항원 등이 있다. 항원전달능력이 있는 랑게로 한스 세포는 Interlukin-1을 생산하여 $\mathrm{T}$ 림프구 활성화을 유도하고 면역학적 갑시 기능을 갖 는다 ${ }^{3,6.12 .19 .25)}$.

$\mathrm{Lim}$ 등 ${ }^{14}$ 과 $\mathrm{Lim}$ 과 Saunders ${ }^{151}$ 는 전자현미경 을 이용한 형태학적 관찰을 통해 진주종의 상 피는 고막의 상피와 동일하지만 랑게르한스 세포가 정상 피부에 비하여 진주종 조직에서 더 많이 존재한다는 것이 알려진 후 중이 진 주종에서 랑게르한스 세포의 역할에 대한 연 구가 국내에서도 활발히 연구되어 왔다. 특히 골파괴를 수반하는 생물학적 톡성에 대한 워 인으로써 랑게르한스 세포의 면역학석 연구가 진행되어 왔다.

저자들은 단클론항체를 이용한 면역조직화 학적 관찰법을 이용하여 중이 진주종과 만성 중이염으로 수술했던 환자를 대상으로 진주종 기질, 만성중이염의 염증성 고막과 인접한 외 이도 피부조직을 채취하여 랑게르한스 세포, $\mathrm{T}$ 림프구의 존재를 확인하였다. 랑게르한스 세 포, $\mathrm{T}$ 립프구, $\mathrm{B}$ 림프구 등의 세포는 항원성 자극에 따라 이주하는 면역세포로 이들 세포의 분포상태를 관찰함으로써 면역학적 체계 및 중이 진주종과 만성중이염의 병태생리학적 차 이를 이해하고자 하였다.

\section{대 상 및 방 법}




\section{1. 대상}

본 연구에서는 중이 진주종 25 명, 만성중이 염 15 명을 대상으로 중이 수술과정에서 조직을 박리하여 채취하였다. 랑게르한스 세포의 수 및 $\mathrm{T}$ 립프구의 분포를 관찰하기 위하여 진주 종 기질, 만성중이염 환자의 염중성 고막과 인 접한 외이도 피부조직을 채취하였다. 대조군으 로는 후이개 절개부위의 정상 피부조직을 채 취하였다.

\section{2. 방법}

대상 조직내의 랑게르한스 세포, $\mathrm{T}$ 림프구의 분포를 관찰하기 위하여 단클론항체를 이용한 면역조직화학적 방법으로 염색하였다.

본 실험에 이용한 일차 항체들은 랑게르한스 세포에 대해서는 rabbit-anti S-100 단백 (DAKO사, USA)과 $\mathrm{T}$ 림프구는 human leukocyte antigen(CD3, DAKO사, USA), 활성화된 $\mathrm{T}$ 림프구는 HLA-DR(DAKO사, USA), B 림프구 는 $\mathrm{CD} 26$ (DAKO사, $\mathrm{USA}$ ), 대식구는 $\mathrm{CD} 68$ (DAKO사, USA)를 이용하였으며, 이차 항체및 발색제로써는 horseradish peroxidase를 이용 한 avidin biotin complex(ABC)법을 이용하였 다. 염색방법은 통상적인 파라핀 고정과 탈회 과정을 거쳐 파라핀에 포매하고 $5 \mu \mathrm{m}$ 두께의 연 속절편을 만들었다. Xylene에 담구어 탈파라핀 하고 알코을을 거쳐 증류수로 함수시켰다. 그 후 phosphated-buffered saline(PBS, pH 7.6)에 5 분간 거친 후 다시 $\mathrm{PBS}$ 로 2 분 정도 수세하 였다. 일차 항체에 대한 반응은 각 일차 항체를 $\mathrm{PBS}$ 에 20 배 희석하여 실온에 30 분간 둔 후 PBS로 수세하였다. 그후 biotin과 결합된 이차 항체 (biotinylated anti-rabbit Ig 또는 biotinylated anti-mouse $\mathrm{Ig}$ )를 도포하여 30 분간 둔 후, PBS로 2분 정도 씻고 avidin biotin peroxidase reagent를 도포하여 30 분간 반응시켰다. 다시 증류수에 1 분간 둔 후 발색제인 $\mathrm{DAB}$ (diaminobenzidine-4 HCL,DAKO) $0.1 \mathrm{mg}$ 과 기 질액인 $\mathrm{H}_{2} \mathrm{O}_{2} \quad 0.02 \mathrm{~mL}$ 를 Tris-buffer $100 \mathrm{~mL}$ 를 섞어 반응시켰다. Hematoxylin 대조염색후 통 상적인 탈수과정을 거쳐 crystal mount로 봉입
하고 광학 현미경으로 관찰하였다.

진주종 기질과 만성중이염 조직, 대조군의 랑게르한스 세포의 분포를 관찰하기 위하여 확대배율 400 배에서 무작위로 선택한 6 시야에 서 나타나는 세포수를 합산하여 평균 갯수를 구하였다. 상피하 결체조직의 염증성 병변 정 도는 염중세포의 수에 따라, $\mathrm{T}$ 림프구의 활성 화 정도는 동일조직내의 전체 림프구 수와 HLA-DR 양성 립프구 수를 비교하여 증가 정 도를 관찰하였다.

통계학적 검중은 다자간의 유의성을 검증하 기 위하여 ANOVA test를 하였으며 P value가 0.05 이하인 경우 그리고 사후다증검사인 $\mathrm{Fi}$ sher's PLSD를 함께 시행하여 $95 \%$ 이상인 경 우 통계학적 의의가 있는 것으로 판정하였다.

\section{결 과}

후이개 정상 피부조직의 표피층은 뚜렷한 4 개충이 관찰되는 중충편평상피였으며 상부 진 피는 섬유아세포와 가는 교원섬유로 구성되어 있었다(그립 1). 랑게르한스 세포는 표피충에 서 $5.3 \pm 2.17$ 개, 진피충에서는 $3.8 \pm 1.56$ 개 관찰 되었다. $\mathrm{T}$ 립프구는 표피충에서 $0.2 \pm 0.1$ 개, 진 피충에서는 $9.1 \pm 2.09$ 개 관찰되었다(표 1).

중이 진주종 기질의 상피는 중층편평상피였 으며 각화물질이 현저히 증가되어 있었다. 면 역조직화학적염색 결과 랑게르한스 세포는 상 피층 $17.8 \pm 6.76$ 개, 진피층 $16.4 \pm 8.14$ 개였으며, $\mathrm{T}$ 립프구는 상피충 $2.4 \pm 1.27$ 개, 진피충 $39.5 \pm$ 14.36 개였다(표 1). 랑게르한스 세포의 분포는 상피충의 Suprabasal layer와 진피상부에서 뚜 렷이 증가하였으며, 분포 양상은 몇 개의 랑게 르한스 세포가 Cluster형태를 취하는 경우와 산재되어 분포하는 경우로 표피와 진피의 접 합부위에서 저명하였다 $(\mathrm{P}<0.05)$. 상피하 결체 조직의 침윤된 염증세포는 대부분 $\mathrm{T}$ 림프구였 으며, $\mathrm{B}$ 립프구, 대식구 둥은 소수 관찰되였다. 중이 진주종 기질에는 만성중이염에서 보다 더 심한 염중성 병변을 보였으며 염증세포의 침 

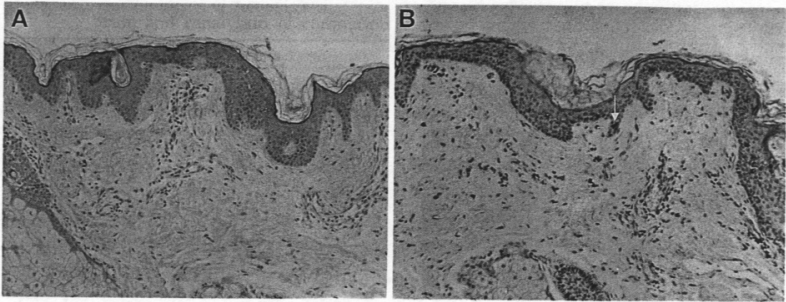

Fig. 1. A. Epidermis of post auricular skin has distinct cell layers and papillary dermis is composed of thin collagen bundles ( $\mathrm{H} \& \mathrm{E}$ stain, $\times 100)$.

B. Langerhans cells (arrow) within the epidermis of post auricular skin (Immunohistochemical stain for S-100 protein, $\times 100$ ).
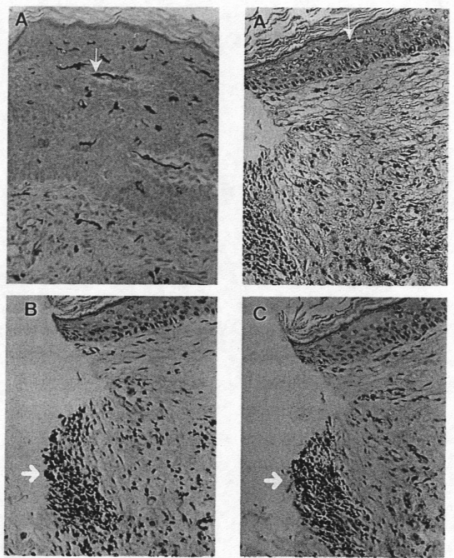

Fig. 2. A. Langerhans cells(arrow) showing elongated dendritic process distributed in the suprabasal layer of epidermis of cholesteatoma matrix (Immunohistochemical stain for S-100 protein, $\times 200$ )

B. Clusters of activated $\mathrm{T}$ cells(arrow) in the subepithelial layer of cholesteatoma matrix (Immunohistochemical stain for HLA-DR, $\times 200$ )

C. Clusters of T cells(arrow) in the subepithelial layer of cholesteatoma matrix (Immunohistochemical stain for $\mathrm{CD} 3, \times 200$ ). 

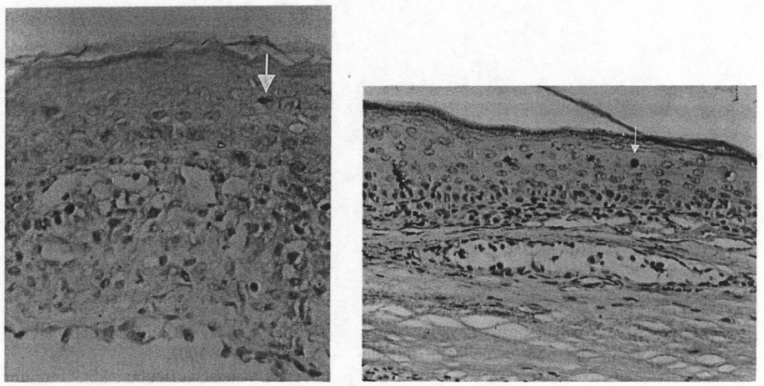

Fig. 3. S-100 protein positive Langerhans cells(arrow) in infected ear drum of chronic otitis media(Immunohistochemical stain for S-100 protein, $\times 200$ ).

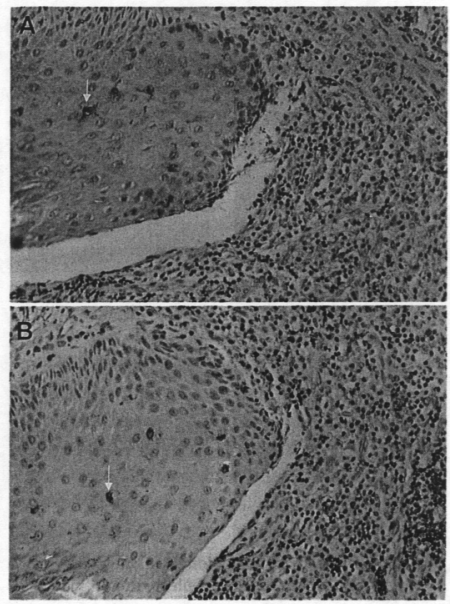

Fig. 4. A. Langerhans cells(arrow) showing simple structure in infected canal skin of chronic otitis media(Immunohistochemical stain for S-100 protein, $\times 200$ ).

B. Activated T cells(arrow) infiltrated in the subepithelial layer of chronic otitis media(Immunohistochemical stain for HLA-DR, $\times 200$ ). 
Table 1. Cell numbers of Langerhans cells and $\mathrm{T}$ cells in cholesteatoma matrix, infected ear drum and canal skin of chronic otitis media, and post auricular skin $(\mathrm{M} \pm \mathrm{SD})$

\begin{tabular}{lcccc}
\hline & Epidermis & & \multicolumn{2}{c}{ Dermis } \\
\cline { 2 - 5 } $\begin{array}{l}\text { Cholesteatoma } \\
\text { matrix }\end{array}$ & LC & T cell & LC & T cell \\
\hline $\begin{array}{l}\text { Infected } \\
\text { ear drum }\end{array}$ & $17.8 \pm 6.76$ & $2.4 \pm 1.27$ & $16.4 \pm 8.14$ & $39.5 \pm 14.36$ \\
\hline $\begin{array}{l}\text { Infected } \\
\text { canal skin }\end{array}$ & $10.7 \pm 3.95$ & $2.1 \pm 1.22$ & $3.9 \pm 2.20$ & $10.0 \pm 3.66$ \\
$\begin{array}{l}\text { Post auricular } \\
\text { skin }\end{array}$ & $5.3 \pm 2.17$ & $0.2 \pm 0.1$ & $3.8 \pm 1.56$ & $9.1 \pm 2.09$ \\
\hline & $\mathrm{P}<0.05$ & $\mathrm{P}>0.05$ & $\mathrm{P}<0.05$ & $\mathrm{P}<0.05$ \\
\hline
\end{tabular}

cell numbers/HPF

윤이 많을수록 랑게르한스 세포와 $\mathrm{T}$ 림프구의 수가 증가하였으며 활성화 정도도 증가하였다 (그림 2 ).

만성중이염의 염중성 고막에서 랑게르한스 세포는 상피충 $6.2 \pm 2.63$ 개, 진피충 $3.9 \pm 2.20$ 개 였으며, $\mathrm{T}$ 림프구의 분포는 상피층 $2.1 \pm 1.22$ 개 진피충 $10.0 \pm 3.66$ 개였다. 염증성 외이도피부에 서의 랑게르한스 세포는 표피충에서 $10.7 \pm 3.95$ 개 진피층에서는 $6.3 \pm 2.82$ 개였으며, $\mathrm{T}$ 림프구 는 표피충에서는 $2.0 \pm 1.25$ 개 진피층에서는 $27.8 \pm 6.49$ 개였다(표 1). 만성중이염에서 랑게 르한스 세포는 고막의 상피층과 외이도 표피 층에서 증가하였으며 상피하 결체조직에서 염 증성 세포의 침윤은 중이 진주종에 비하여 적 었으며 랑게르한스 세포, $\mathrm{T}$ 림프구 수도 적 었다(그림 3,4 ).

\section{고 안}

피부는 표피, 진피, 피하조직으로 구성되어 있으며, 이중 표피층이 면역학적으로 가장 중 요한 역할을 한다. 이는 신체의 가장 외부에 있는 조직으로 대부분 각질형성세포로 구성되 어 있으나 그외에 멜라닌 세포, 랑게르한스 세 포, Merkel 세포등이 있다. 두께는 0.04 1.5m 이며 가장 외측은 각질충이며, 가장 내측은 기
저층으로 기저세포로 되어있다 ${ }^{12}$.

Sauder 등 ${ }^{19}$ 은 표피조직내의 $80 \sim 90 \%$ 를 점 유하고 있는 각질형성세포의 세포막에는 항워 을 식별할 수 있는 수용체가 있으며 랑게르한 스 세포와 더불어 면역기전에 중요한 역할을 한다고 하였다. 랑게르한스 세포는 표피조직 구성세포 중 약 $3 \sim 4 \%$ 를 점유하고 ${ }^{25 k}$ 주로 suprabasal layer에 존재하며 세포수는 사람에서 $460 \sim 1000 / \mathrm{mm}^{2}$ 로 부위에 따라 차이가 있다고 하였다. 랑게르한스 세포는 피부외에 구강점 막, 식도, 질, 비장, 홈선, 임파절, 정상 진피에 서도 발견이 된다 ${ }^{20 y}$. Katz 등⒈3은 랑게르한스 세포는 대식세포-단세포-조직세포 계열의 세포 로 골수기원 세포이며, 표피와 진피사이 등을 이주할 수 있는 세포라 하였다 121:12121:21).

랑게르한스 세포의 관찰방법은 통상적인 $\mathrm{H}$ $\mathrm{E}$ 염색에서는 투명한 세포질을 갖는 세포로 잘 나타나지 않으며 특수 염색방법으로 $\mathrm{AT}$ Pase와 alpha-D-mannosidase 염색법, Goldchloride 염색법, L-dopa 형광법이 있다. 전자 현미경 소견으로는 세포 형태는 쭈그러진 모 양으로 겹쳐진 핵과 세포질내에 특유한 $\mathrm{Bir}$ beck 과립을 가지고 있다. 최근 단클론항체 OKT-6(T6, Leu6, CD1), HLA-DR(Ia) 항체 등 을 이용한 면역조직화학적염색 방법의 개발로 랑게르한스 세포의 관찰 및 정성적, 정량적 분 석에 많이 이용되고 있다. 당게르한스 세포에 
존재하는 표면항원으로는 CD1, T200, HLA-DR (Ia)이 있고 세포질 항원으로 S-100 단백이 있 다 ${ }^{12)}$. Ia 항원이나 OKT-6의 표면항원은 자외선 자극이나 부신피질호르몬제의 영향으로 표지 자의 발현을 감소시켜 항원제시기능이 감소한 다 ${ }^{26)}$. 또한 항원성 유지를 위하여 동결절편을 이용해서 염색해야 하나 안정성이 높고 포르 말린에 고정하여 파라핀 포매방법으로 편리하 게 관찰할 수 있는 S-100 단백 항체를 이용한 랑게르한스 세포 염색법이 중이 진주종에서 랑게르한스 세포 관찰 및 정량적 분석에 유용 한 방법으로 이용되고 있다. S-100 단백은 중 추신경계의 슈반세포에도 관찰이 되지만 상피 조직내의 랑게르한스 세포를 규명하는데 유용 한 표지로 사료된다. 저자 등은 안정성이 높고 포르말린 고정, 파라핀 포매방법으로 이용이 편리한 S-100 단백과 HLA-DR 항원를 이용한 염색 방법으로 랑게르한스 세포의 관찰 및 정 량분석과 활성화된 $\mathrm{T}$ 립프구와의 관계을 관찰 하였다. HAL-DR 항원을 이용한 염색방법은 랑게르한스 세포뿐 아니라 활성화된 $\mathrm{T}$ 립프구, $\mathrm{B}$ 림프구, 대식세포에도 염색이 되며 활성화된 $\mathrm{T}$ 림프구를 관찰하는데 많이 이용된다.

랑게르한스 세포는 기능 및 면역학적으로 대식세포와 같은 계통으로 골수로 부터 유래 하며 미세구조상 Birbeck 과립을 가지고 있다. 대식세포와 같이 세포 표면에 Ia항원(ClassII 혹은 HLA-DR항원)이 존재하며 IgG의 Fc Portion에 대한 수용체와 모체의 $\mathrm{C} 3 \mathrm{~b}$ component 의 수용체가 있다 ${ }^{21}$. 이런 표지는 항원의 인지 와 $\mathrm{T}$ 세포와의 상호작용에 중추적 역할을 할 것으로 보인다. 랑게르한스 세포는 $\mathrm{T}$ 세포에 항 원을 제시하기 전에 이것을 처리하는데 간여 하며 항원 특이성 $\mathrm{T}$ 세포 증식을 자극하거나 Interleukin-1과 같은 비특이성 항원 증폭인자 를 분비하여 $\mathrm{T}$-세포 활성화에 관여한다. Interleukin-1은 랑게르한스 세포와 각질형성세포에 서 생산되며 $\mathrm{T}$-세포 활성화에 상호작용하며 각질형성세포는 랑게르한스 세포와 더불어 피 부면역기전에 중요한 역할을 한다.12,19). 이와같 이 랑게르한스 세포는 알레르기성 접촉피부염,
이식거부, 면역내성, 바이러스감염 및 피부신 생물에 대한 면역학적 감시기능을 할 것으로 보인다. 반면에 랑게르한스 세포의 수 또는 기 능이 감소하면 면역감시기능이 감소하여 특수 면역내성, 악성종양, 감염 등을 초래할 수 있을 것이라 하였다. 실제로 각막부위에는 allograft 의 거부반응에 관여하는 랑게르한스 세포가 거의 존재하지 않으므로 allograft 각막이식의 성공율이 매우 높다고 하였다 ${ }^{12)}$. 최근 Ohtsuki 등ㄱㄱㄱㅘ Furihata 등근 피부악성종양과 식도암 환자의 예후지표로 HLA-DR 항원과 S-100 단 백을 이용한 염색방법으로 양성 1 인 Dentritic cell의 침윤이 종양 주위에 많은 경우 그렇지 않는 경우보다 예후가 더 좋았다고 하였다. 이 처럼 랑게르한스 세포는 면역학적 계열에서 가장 말초적 전초기지의 최전방 요소이며 면 역학적으로 중요한 세포이다 ${ }^{21.25)}$. 이와같이 면 역학적으로 중요한 세포가 1868년 Paul Langerhans에 의해 발견되어 전자 현미경적 연 구가 시작한 1950년대까지 별다른 연구가 없 었다 ${ }^{12)}$.

$\mathrm{Lim}$ 등 ${ }^{14}$ 과 $\mathrm{Lim}$ 과 $\mathrm{Saunder}^{15)}$ 는 전자현미경 을 이용한 진주종 상피에 대한 형태학적 관찰 을 통해 진주종 상피는 고막상피조직과 동일 하며 정상 피부에 존재하는 랑게르한스 세포가 중이 진주종 상피에서 더 많이 발견되었다고 기술한 이래 중이 진주종에서도 랑게르한스 세포가 존재한다는 것이 알려졌다. 최근 중이 진주종의 병인 및 병태생리, 골파괴에 대한 연 구가 랑게르한스 세포를 대상으로 활발히 이 루어져 왔으나 랑게르한스 세포의 면역학적 역활에 대해서는 아직 확실하게 규명되어 있지 않다.

중이 진주종에 의한 골파괴 기전은 확실하게 규명되어 있지 않으나 탈락된 표피의 각질이 축적되어 압박괴사, 파골세포성골흡수, collagenase와 lysozyme 효소에 의한 골융해로 골 결손을 일으키게 된다고 하였다 ${ }^{3}$. 랑게르한스 세포에 의해 활성화된 $\mathrm{T}$ 림프구와 여러 세포로 부터 분리된 lymphokin은 국소적 또는 전신적 면역반웅을 조절하는데 관여하며 랑게르한스 
세포등에서 분비된 Interleukin-1은 T림프구 활성화에 직접적인 영향을 미치며 상호작용으 로 파골세포의 유입을 초래하여 파골세포성 골홉수를 초래하는 것으로 보고하고 있다. 또 한 Interleukin-1은 섬유아세포와 대식세포를 자극하여 collagenase, prostaglandin 을 형성하 며 이는 진주종에 의한 골파괴에 중요한 역활 을 한다고 하였다 ${ }^{3}$. 중이 진주종에 염증성 병 변이 수반하면 진주종의 중식이 빨라지고 골 파괴가 심하게 일어나는데 이는 진주종 상피 내의 세포분열을 촉진하고 상피하조직의 염중 성 세포들이 collagenase 와 lysosomal enz$\mathrm{yme}$ 을 생성하여 골흡수 과정에 관여하며 이러 한 만성염중성 반응을 조절하는데 랑게르한스 세포가 관여할 것으로 보인당. 그러나 중이 진주종과 만성중이염의 상피하층의 육아조직 은 형태학적, 생화학적으로 유사하나 실제 임 상적으로는 중이 진주종 환자에서 골파괴 정 도가 더 심하고 합병증이 많다. 이에 대하여 $\mathrm{Gant} \mathrm{z}^{\mathrm{g})}$ 는 진주종의 각화편평상피가 골파괴에 관여할 것이라 하였으나 진주종의 상피층에 대한 역할에 대해서는 좀더 연구가 필요할 것 으로 사료된다.

Palva 둥 ${ }^{18)}$ 은 만성중이염 환자의 육아조직 혹은 결체조직의 분비상피에서 랑게르한스 세 포를 관찰하였으며 정상 면역방어세포로 추정 하였다. 또한 체액분비성 $\operatorname{IgA}$ 방어기전이 부족 한 피부에서 랑게르한스 세포의 증가는 면역 방어체계에 중요한 역할을 한다고 하였으며 진주종의 각화과정과 형성에 관여한다는 어떤 증거도 없다고 하였다.

저자등은 중이 진주종과 만성중이염의 임상 적 또는 병태생리학적 차이점을 이해하고자 본 연구를 시도하였다. 중이 진주종 기질에서 랑 게르한스 세포의 분포는 상피충의 suprabasal layer와 진피상부에서 뚜렷이 증가된 양상을 보였으며 표피와 진피 접합부위 에서 저명하 였다. 만성중이염의 염중성 고막과 외이도 피 부 조직에서 랑게르한스 세포는 상피충에서 증가하였다. $\mathrm{Gantz}^{8)}$ 는 정상 고막에는 외이도 피부보다 훨씬 적은 소수의 랑게르한스 세포가
존재한다고 하였으며, 저자등의 결과에서 염증 성 고막에 존재하는 랑게르한스 세포와 대조 군간의 비교에서 통계학적 유의성은 없었으나 ( $\mathrm{P}>0.05)$, 정상 고막과 비교한다면 염중성 고 막에서 랑게르한스 세포는 증가되어있는 것으 로 여겨진다. 상피하결채조직에서 염증성 병변 의 정도는 중이 진주종에서 만성중이염보다 더 심하였으며 염증성 병변의 증가 정도에 따라 랑게르한스 세포와 $\mathrm{T}$ 림프구의 수, $\mathrm{T}$ 림프구의 활성화 정도도 증가하였다. 중이 진주종과 만 성중이염 조직에서 랑게르한스 세포의 분포, $\mathrm{T}$ 림프구의 활성화 정도는 다소 차이가 있음을 알 수 있었으며, 이러한 면역세포의 분포 차이 특히 상피하 결체조직에서의 랑게르한스 세포 와 $\mathrm{T}$ 립프구의 분포 차이는 염증성 병변의 유 지 및 조절에 밀접한 관계가 있을 것으로 사 료된다. 독소, 기생충, 비특이성 혹은 특이성 항원, 암세포, 미생물 등에 노출이 되면 신체 방어기전으로 랑게르한스 세포의 수는 증가하 게 되고 $\mathrm{T}$ 림프구의 할성화, lymphokin 분비 등의 일련의 면역반응을 초래한다. 이는 신체 방어기전으로써 정상적인 면역감시체계의 일 환으로 보이며 랑게르한스 세포는 이를 수행 하는 정상 면역방어세포로 사료되나 중이 진 주종의 병태생리 및 골파괴 기전 등에 대한 역할에 대하여는 좀더 많은 연구가 필요할 것 으로 사료된다.

\section{결 론}

저자들은 중이 진주종 및 만성중이염의 조 직에서 랑게르한스 세포 및 $\mathrm{T}$ 림프구의 정량 적 분석에 의한 분포차이를 관찰하여 다음과 같은 결론을 얻었다.

1) 중이 진주종 기질내 랑게르한스 세포는 상피충의 suprabasal layer와 진피상부에서 뚜 렷이 증가된 양상을 보였으며 표피와 진피의 접합부위에서 저명하였다. 랑게르한스 세포의 수는 만성중이염이나 대조군보다 더 증가하였 다 $(\mathrm{P}<0.05)$, 만성중이염의 조직에서 랑게르한 
스 세포는 고막상피층 혹은 외이도 표피충에서 진피충보다 중가된 소견을 보였으며, 랑게르한 스 세포 수는 대조군보다 증가하였으나 세포 형태는 단순하였다 $(\mathrm{P}<0.05)$.

2) 상피하 결체조직의 랑게르한스 세포 및 $\mathrm{T}$ 립프구의 중가는 중이 진주종에서 만성중이 염보다 증가되어 있었으며, 중이 진주종에서 염증성 병변의 정도도 심하였다. 염증성 병변 의 정도가 심할수록 랑게르한스 세포 및 활성 화된 $\mathrm{T}$ 림프구 수도 증가하였다 $(\mathrm{P}<0.05)$.

이상의 결과에서 중이 진주종은 만성중이염 조직과 비교하여 랑게르한스 세포, $\mathrm{T}$ 립프구의 분포차이를 관찰할 수 있었으나 중이 진주종 에서 랑게르한스 세포의 면역학적 역활에 대 하여는 더 많은 연구가 필요할 것으로 사료된 다.

\section{References}

1) 박기현 - 정명현 · 김희남 등 : 면역조직학 적 방법을 이용한 중이진주종의 랑게르 한스 세포에 관한 연구. 한이인지 35 : $840 \sim 846,1992$

2) 성명훈·이창순 - 이철희 둥 : 중이진주종 조직에서의 랑게르한스 세포 및 림프구 의 분포에 관한 면역조직화학적 연구. 한 이인지 $36: 15 \sim 23,1993$

3) Ahn JM, Huang CC, Abramson M : Interleukin 1 causing bone destruction in middle ear cholesteatoma. Otolaryngol $\mathrm{H}$ \& N surg $103: 527 \sim 536,1990$

4) Bernstein J, Hausmann E, Wright J : Middle ear disease release of soluble factors stimulating bone resorption. In McCabe B, Sade J, Abramson M, eds. cholesteatoma: first international conference. Birmingham, Alabama, Aescuplapius co, pp152 61, 1977

5) Dahl WV: The Immune System in HeaIth and Disease. In Moschella SL, Hur- ley HJ, 3rd ed. Dermatology, Saunders Co. pp243 249, 1992

6) Frankel S, Berson S, Godwin T, et al : Differences in dentritic cells in congental and acquired cholesteatoma. Laryngoscope $103: 1214 \sim 1217,1993$

7) Furihata $M$, Iwata $J$, sonobe $H$, et al : HLA-DR antigen and/or S-100 protein positive dentritic cells as prognostic indicators in esophageal squamous cell carcinoma. proceedings of third KoreanJapanese lymphoreticular workshop, pp $227 \sim 235,1993$

8) Gants BJ : Epidermal Langerhans cells in cholesteatoma. Ann Otol Rhinol Laryngol $93: 150 \sim 156,1984$

9) Gantz BJ, Clancy C, Abramson M : Decalcification factors in grannulation tissue and ear canal skin. In McCabe B, Sade J, Abramson M, eds. Cholesteatoma : first international conference, Birmingham, Alabama, Aesculapius co, pp 167 169, 1977

10) Gantz BJ, Maynard J, Bunsted R, et al $:$ Bone resorption in chronic otitis media. Ann Otol Rhinol Laryngol 88: 693 700, 1979

11) Green RM, Cordero A, Winkelman RK : Epidermal mast cells. Arch Dermatol 113: 166 169, 1977

12) Jakubovic $H R$, Ackerman $A B:$ Structure and function of skin: Development, Morphology, and physiology. In Moschell SL, Hurley HJ, 3rd ed. Dermatology, saunders Co. pp 3 87, 1992

13) Katz SI, Tamaki K, Sachs DH : Epidermal Langerhans cells are derived from cells originating in bone marrow. Nature 282:324 326, 1979

14) Lim DJ, Birck HG, Saunders WH : Aural cholesteatoma and epidermization: A 
fine morphological study. In McCabe B, Sade J, Abramson M, eds. cholesteatoma : first international conference. Birmingham, Alabama, Aescuplapius co, pp 233 252, 1977

15) Lim DJ, Saunders WH : Acquired cholestreatoma. Ann Otol Rhinol Laryngol 81 : 2 12, 1972

16) McGill TJ, Merchant S, Healy GB, et al : Congenital cholesteatoma of the middle ear in children, a clinical and histopathological report. Laryngoscope 101 : 606 613, 1991

17) Ohtsuki $Y$, Manabe $Y$, Furihata $M$, et al: Immunohistochemical analysis of $\mathrm{S}$ 100 protein positive dentritic cells in human cutaneous squamous cell carcinomas, Bowen's diseases and basal cell carcinomas, Proceedings of third Korean-Japanese lymphoreticular workshop. pp 227 235, 1993

18) Palva $\mathrm{T}$, Taskinen $\mathrm{E}$ : Langerhans cells in chronic otitis media. Acta Otolaryngol (Stockh) 103:448 450. 1987

19) Sauder DN, Dinarello CA, Morhenn V, et al : Langerhans cell production of Interleukin-1. Clin Research $32: 258 \mathrm{~A}$, 1984
20) Silberberg I, Baer RL, Rosenthal SA. et al: Dermal and intravascular langerhans cells at sites of passively induced allergic contact sensivity. Celluar Immunol $18: 435 \sim 453,1975$

21) Stingel G, Wolff-Schreiner EC, Pichler WJ, et al: Epidermal Langerhans cells bear Fc and $\mathrm{C} 3$ receptors. Nature 268 : 245 246, 1977

22) Takahashi S, Nakano $Y:$ Immunohistochemical demonstration of Langerhans cell in cholesteatoma using on antiserum against S-100 protein. Arch Otorhinolaryngol $264: 48 \sim 52,1987$

23) Veldman JE, Visser CE, Shuurman HJ. et al: Immunobiology of Langerhans cells migrating aural cholesteatoma. Otolaryngol H \& N Surg 92:1 6, 1984

24) Winkelmann RK, Breathnach AS: The merkel cell. J Invest Dermatol $60: 2$ 15, 1973

25) Wolff $\mathrm{K}$ : The Langerhans cell and the epidermis: An integrated immune system. J Dermatol 10:401 410, 1983

26) Wolff $\mathrm{K}$, Stingel $\mathrm{G}$ : The Langerhans Cell. J Invest Dermatol Suppl $80: 017$ s 012s, 1983 